\title{
Status „niezależnego" usługodawcy a trójpodmiotowy model świadczenia usług w gig economy - cz. 2
}

\section{The status of 'independent contractor' in the light of three-party model of providing services in the gig economy - part 2}

\author{
mgr Gabriela Gospodarek
}

Uniwersytet Warszawski, Wydział Prawa i Administracji doktorantka w Katedrze Prawa Pracy i Polityki Społecznej

ORCID: 0000-0001-9048-443

\begin{abstract}
Streszczenie W pierwszej części artykułu, opublikowanej w numerze 2/2019 PiZS, scharakteryzowano oraz przedstawiono najważniejsze trendy opisujące zatrudnienie w sektorze gospodarki „na żądanie”. Część druga ma na celu ukazanie tendencji polegającej na stałym wzroście postępowań sądowych z zakresu gig economy, tak istotnych z perspektywy prawa pracy oraz sposobu podejścia sądów do przedstawionych tam zagadnień prawnych. Autorka szczegółowo analizuje dwa najważniejsze i najbardziej komentowane postępowania sądowe przeciwko pionierowi w sektorze gig economy, przedsiębiorstwu Uber, które dotyczyły błędnej klasyfikacji osób zaangażowanych w ten rodzaj zatrudnienia. Wymienia również szereg innych postępowań sądowych dotyczących tego zagadnienia, ukazując specyfikę prawidłowego rozgraniczenia statusu prawnego osoby samozatrudnionej (niezależnego usługodawcy) od standardowego pracownika.
\end{abstract}

Słowa kluczowe: niezależny usługodawca, błędna klasyfikacja, gig economy, Uber, ukryte zatrudnienie, niestandardowe formy zatrudnienia, platforma internetowa, aplikacja, gospodarka na żądanie, spory sądowe.

Summary In the first part of this article, published in the issue 2/2019 PiZS, the Author characterized and presented the overriding trends related to employment in the "on-demand" economy sector. The second part aims to show the tendency of a constant growth in court proceedings concerning gig economy sector, that are of great importance from the labour law perspective and also the courts's approach in solving legal issues outlined there. The Author gives detailed overview of two most important and most disputed court cases from the gig economy sector related to misclassification of people engaged in this form of employment, against Uber. The Author mentions also a number of other legal proceedings deliberating on this problem, reflecting the peculiarities of correct distinction of the legal status of independent contractor in comparison to classic employee.

Keywords: independent contractor, misclassification, gig economy, Uber, disguised employment relationships, nonstandard employment, platform, app, on-demand economy, legal proceedings.

\section{Bibliografia}

Cherry, M. A. (2016). Gig Economy: Settlements Leave Labor Issues Unsettled. Saint Louis University School of Law. Legal Studies Research Paper Series, (9). https://doi.org/10.2139/ssrn.2776213

Davidov, G. (2005). Who is a Worker? Industrial Law Journal, 34, http://www.academia.edu/17924962/Who_is_a_Worker, https://doi.org/10.1093/ilj/34.1.57

Nyombi, Ch. (2015). A response to the challenges posed by the binary divide between employee and self-employed. International Journal of Law and Management, 57, http://www.eme- raldinsight.com/doi/abs/10.1108/IJLMA-03-2013-0012?journalCode=ijlma, https://doi.org/10.1108/IJLMA-03-2013-0012

Osborne, H. (2016). Uber loses right to classify UK drivers as self-employed. The Guardian z 28 października 2016 , https://www.theguardian.com/technology/2016/oct/28/uber-u- k-tribunal-self-employed-status

Rosenblat, A. Stark, L. (2016). Algorithmic Labor and Informa- tion Asymmetries: A Case Study of Uber's Drivers. International Journal Of Communication, 10(27).

Ross, H. (2015). Ridesharing's House Of Cards: O’Connor v. Uber Technologies, Inc. and the viability of Uber's Labor Model in Washington. Washington Law Review, 90(3).

Williams D. i in. (2014). A Guide to UK Employment Law 2014. Over 15 years' experience of one thing. Rapid change. Kemp Little http://www.kemplittle.com/cms/document/Guide_to_UK_Employment_Law pdf 
